\title{
Effects of gonadotrophin-releasing hormone and prostaglandin F-2 $\alpha$ on corpus luteum function and timing of the subsequent ovulation in the mare
}

\author{
A. L. Johnson, S. E. Becker and M. L. Roma \\ Department of Animal Sciences, Rutgers, The State University, New Brunswick, NJ 08903, U.S.A.
}

\begin{abstract}
Summary. Standard bred mares that were cycling normally were treated beginning on Days 9 or 10 of the oestrous cycle with repeated pulses of $\mathrm{GnRH}(20 \mu \mathrm{g} / \mathrm{h})$ and/or a single injection of prostaglandin (PG)F-2 $\alpha$ (alfaprostol, $3 \mathrm{mg}$ ), and were subsequently bled and palpated daily until the next ovulation. GnRH treatment increased serum concentrations of $\mathrm{LH}$ and progesterone at 4 days after the start of treatment compared to controls. The combination of PGF- $2 \alpha+\mathrm{GnRH}$ treatment resulted in an immediate decline in serum progesterone values, and subsequently decreased the interval to next ovulation by 4.5 days compared to controls. Mean serum concentrations of FSH were not different among treatment groups 4 days after the start of treatment, and there was a consistent trend among all treatment groups for decreasing concentrations of FSH within the 6 days before ovulation. We conclude that, under our experimental conditions, pulsatile administration of GnRH provides a short-term luteotrophic stimulus, probably by the elevation in serum $\mathrm{LH}$, but that this stimulus cannot indefinitely prevent the luteolytic effects of exogenously administered PGF-2 $\alpha$. Although GnRH treatment combined with PGF- $2 \alpha$ injection hastened the impending ovulation, this regimen was no more effective than PGF-2 $\alpha$ treatment alone.
\end{abstract}

Keywords: mare; ovulation; LH; FSH; progesterone; corpus luteum; PGF-2a

\section{Introduction}

Concentrations of prostaglandin (PG) F-2 $\alpha$ increase in uterine venous blood of the mare at the time of luteal regression and before the decline in serum progesterone values (Douglas \& Ginther, 1976). Administration of PGF- $2 \alpha$ or its analogues after Day 4 of the ovulatory cycle induces premature luteal regression and a return to oestrus within approximately 3 days (Douglas \& Ginther, 1972; Noden et al., 1974; Kiefer et al., 1979), and it has been suggested that PGF-2 $\alpha$ is the major luteolytic factor in the mare (Ginther, 1979). On the other hand, little work has been conducted to identify potential luteotrophic factors. Studies which found that administration of human chorionic gonadotrophin or an equine pituitary extract, beginning on Day 9 of the cycle, could prolong the active life of the corpus luteum (CL) (Ginther, 1979), along with studies which found that passive immunization with an anti-serum against an equine pituitary fraction induces luteal regression (Pineda $e t$ al., 1972), suggest that the presence of luteinizing hormone (LH), or possibly follicle-stimulating hormone $(\mathrm{FSH})$, is required for luteal maintenance.

In the ewe, continuous administration of LH (Karsch et al., 1971), or injection of gonadotrophin-releasing hormone (GnRH) at 2-h intervals (Adams et al., 1975), extends the lifespan of the $\mathrm{CL}$, presumably via the luteotrophic actions of $\mathrm{LH}$. The present study was conducted to determine whether pulsatile administration of GnRH to normal, cycling mares during the late luteal phase 
could: (1) increase serum concentrations of progesterone or prolong the duration of dioestrus; (2) overcome the luteolytic effects of exogenously administered PGF-2 $\alpha$; and (3) decrease the interval to the subsequent ovulation when compared to control and PGF-2 $\alpha$-treated mares.

\section{Materials and Methods}

Sixteen standardbred mares between the ages of 5 and 24 years were studied. Diet consisted of seasonal pasture and mixed hay. Water and trace mineralized salt were available at all times. All mares were teased with a pony stallion and bled $(5.0 \mathrm{ml}$, by jugular venepuncture) a minimum of 3 times per week before the study. Ovulation cycles were evaluated by noting behavioural oestrus and serum progesterone concentrations, and by monitoring ovarian morphology with ultrasound scanning or rectal palpation. The studies reported were conducted under ambient photoperiod during the months of May through August in New Jersey $\left(40^{\circ} 30^{\prime} \mathrm{N}\right)$.

Mares were randomly assigned to one of four groups, and treatment was initiated 9 or 10 days after ovulation. The treatments consisted of vehicle (sesame oil and/or saline, $0.154 \mathrm{M}-\mathrm{NaCl}$ ), the PGF-2 $\alpha$ analogue, alfaprostol ( $3 \mathrm{mg}$; Alfavet, Hoffman-LaRoche, Nutley, NJ) and/or GnRH $(20 \mu \mathrm{g}$ administered as a 5-6 sec pulse, once per h; Sigma Chemical Co., St Louis, MO) as follows: Group 1, PGF-2 $\alpha$ vehicle plus GnRH vehicle (control; $N=4)$; Group 2, PGF-2 $\alpha$ plus GnRH vehicle (PGF-2 $\alpha$; = 6); Group 3, PGF-2 $\alpha$ vehicle plus GnRH (GnRH; $N=6)$; and Group 4, PGF- $2 \alpha$ plus GnRH $(N=6)$. Each group included one mare for which treatment was started on Day 9 after ovulation, with the remaining mares being treated from Day 10. Prostaglandin F-2a or the oil vehicle was administered as a single 3-ml injection, i.m., while GnRH or saline vehicle was infused in a pulsatile fashion $(118 \mu \mathrm{l} / \mathrm{h})$ using an Autosyringe infusion pump (Model AS 2H, Autosyringe, Inc., Hooksett, NH), as previously described (Johnson, 1986, 1987). Infusion of GnRH or its vehicle was continued until 1 day after the subsequent ovulation. All mares were housed individually in box stalls throughout the infusion period. Six mares were used for two different treatments, but never in successive oestrous cycles.

Blood samples $(5.0 \mathrm{ml})$ were withdrawn by venepuncture from the jugular contralateral to the infusion catheter before (Day 0 ), and once daily after, the start of the experiment. Serum samples were stored at $-20^{\circ} \mathrm{C}$ until assayed for progesterone (Malinowski et al., 1985), LH (Johnson, 1986) and FSH (Johnson, 1987). The sensitivities of the assays were $0.2 \mathrm{ng}$ progesterone $/ \mathrm{ml}, 0.6 \mathrm{ng} \mathrm{LH} / \mathrm{ml}$ and $8 \mathrm{ng} \mathrm{FSH} / \mathrm{ml}$ and the intra- and inter-assay coefficients of variation were 14 and $11 \%$ for progesterone, 11 and $5 \%$ for LH and 6 and $15 \%$ for FSH. Ovulation was detected by ultrasound scanning, or in some cases by rectal palpation, and was subsequently verified by the observance of an increase in serum progesterone within $48 \mathrm{~h}$ of ovulation (Ginther, 1979). No attempt was made to determine the number of follicles ovulated in individual mares.

The effect of each treatment was evaluated by monitoring the days to the termination of the luteal phase (serum progesterone $<1.0 \mathrm{ng} / \mathrm{ml}$ ), and the days to ovulation. Days to the termination of the luteal phase and to ovulation were analysed by the Kruskal-Wallis test, and significant interactions were partitioned by a non-parametric multiple comparison test (Zar, 1984). Before analysis of hormone concentration data, values were transformed to logarithms to normalize the variance between treatments (Snedecor \& Cochran, 1967). A post-hoc comparison of the mean serum concentration of progesterone, $\mathrm{LH}$ and FSH between treatments was conducted at Day 4 of treatment by a one-way analysis of variance (ANOVA), and significant interactions were partitioned by the Newman-Keuls multiple range test. Hormone concentrations over time were analysed by a split-plot in time ANOVA (Snedecor \& Cochran, 1967).

\section{Results}

Prostaglandin treatment decreased the number of days from the start of treatment to the end of the luteal phase compared to the control group, whether administered in the absence or presence of pulsatile GnRH treatment $(P<0.05$; Table 1$)$. However, the number of days until the subsequent ovulation was significantly reduced only in the PGF-2 $\alpha+$ GnRH-treated group compared to the controls $(P<0.05)$. One mare in the GnRH-treated group ovulated 10 days after the start of treatment despite the presence of a persistent CL (lowest progesterone value after the start of treatment was $5 \cdot 10 \mathrm{ng} / \mathrm{ml}$ ). No differences were detected for the days to termination of the luteal phase or days to ovulation between the GnRH-treated and control groups.

Serum concentrations of progesterone, $\mathrm{LH}$ and FSH relative to the start of treatment are shown in Fig. 1. There were no significant differences in pretreatment concentrations of progesterone, LH or FSH among treatments $(P>0 \cdot 10)$. By 4 days after the start of treatment, serum progesterone concentrations were decreased in both PGF-2 $\alpha$-treated groups and increased in the GnRH-treated group compared to the control group $(P<0.05$; Table 2$)$. Concentrations of LH 
Table 1. Days (mean \pm s.e.m.) from start of treatment to termination of the luteal phase and to next ovulation in mares

\begin{tabular}{|c|c|c|c|}
\hline \multirow[b]{2}{*}{$\begin{array}{l}\text { Treatment } \\
\text { group* }\end{array}$} & \multirow[b]{2}{*}{$\begin{array}{l}\text { No. of } \\
\text { mares }\end{array}$} & \multicolumn{2}{|c|}{ Days to: } \\
\hline & & $\begin{array}{l}\text { Termination of } \\
\text { luteal phase } \dagger\end{array}$ & $\begin{array}{c}\text { Next } \\
\text { ovulation } \\
\text { (range) }\end{array}$ \\
\hline Control & 4 & $6 \cdot 8 \pm 0 \cdot 3^{a}$ & $\begin{array}{c}10 \cdot 8 \pm 0 \cdot 5^{2} \\
(10-12)\end{array}$ \\
\hline PGF-2 $\alpha$ & 6 & $2 \cdot 2 \pm 0 \cdot 4^{b}$ & $\begin{array}{c}7 \cdot 8 \pm 1 \cdot 2^{a, b} \\
(3-11)\end{array}$ \\
\hline GnRH & 6 & $7.8 \pm 0.3 \ddagger^{a}$ & $\begin{array}{c}8 \cdot 3 \pm 0.9^{\mathrm{a}, \mathrm{b}} \\
(7-12)\end{array}$ \\
\hline PGF- $2 \alpha+$ GnRH & 6 & $2 \cdot 5 \pm 0 \cdot 2^{b}$ & $\begin{array}{c}6 \cdot 3 \pm 0 \cdot 8^{b} \\
(3-9)\end{array}$ \\
\hline \multicolumn{4}{|c|}{$\begin{array}{l}\text { *PGF- } 2 \alpha, 3 \mathrm{mg} \text { alfaprostol; } \mathrm{GnRH}, 20 \mu \mathrm{g} / \mathrm{h} \text {. Treatment began } 9 \text { or } \\
10 \text { days after ovulation. } \\
\text { †Indicated by serum progesterone concentration }<1.0 \mathrm{ng} / \mathrm{ml} \text {. } \\
\text { fOne mare in this group had a low progesterone value of } 5 \cdot 1 \mathrm{ng} / \mathrm{ml} \\
\text { at } 4 \text { days following the start of treatment, and was not included in } \\
\text { this calculation. } \\
\text { a,b Means with different superscripts } \operatorname{differ}(P<0.05) \text {. }\end{array}$} \\
\hline
\end{tabular}

were significantly elevated in both GnRH-treated groups compared to controls $(P<0.05)$. There were no significant differences in serum FSH concentrations among treatment groups $(P>0 \cdot 10)$.

Concentrations of LH and FSH in the four treatment groups aligned relative to day of the subsequent ovulation are depicted in Fig. 2. The peak concentration of LH in each mare, irrespective of treatment, occurred on the day of ovulation, or 1-2 days after ovulation, and there was no difference in the mean periovulatory peak concentration of $\mathrm{LH}$ between treatments (overall mean, $9 \cdot 30 \pm 0.70 \mathrm{ng} / \mathrm{ml} ; P>0 \cdot 10$ ). Mean concentrations of FSH in each treatment group decreased during the 6-day period before ovulation $(P<0 \cdot 05)$, and lowest concentrations in each group occurred 1 day before ovulation.

\section{Discussion}

The rapid decrease in serum progesterone (Fig. 1) following a single injection of the PGF-2 $\alpha$ analogue, alfaprostol, is similar to that previously reported using PGF-2 $\alpha$ (Noden et al., 1974, 1978; Douglas \& Ginther, 1975; Roser et al., 1982) or the PGF-2 $\alpha$ analogues, prostalene (Kiefer et al., 1979) or ICI-81008 (Equimate; Nett et al., 1979). In addition, PGF-2 $\alpha$ treatment on Days 6-8 of the first post-partum dioestrus was found to reduce the interovulatory interval compared to untreated mares, but ovulations occurred over a wide interval of time (2-14 days after treatment; Loy et al., 1979). In the present study the lack of a significant reduction in the number of days to subsequent ovulation in response to PGF-2 $\alpha$ compared to the control group may be due to PGF-2 $\alpha$ being administered at a later stage (Day 9 or 10) of dioestrus, and also to the considerable variability in the number of days to ovulation in PGF-2 $\alpha$-treated mares (3-11 days; Table 1). A significant reduction in the number of days to subsequent ovulation was observed between groups of mares receiving PGF- $2 \alpha+$ GnRH and the control treatment (Table 1), but the former treatment was no more effective than when mares were treated with PGF-2 $\alpha$ alone.

GnRH treatment was unable to overcome the luteolytic effects of exogenously administered PGF-2 $\alpha$, as indicated by a comparable time to termination of the luteal phase (Table 1) and serum progesterone profile (Table 2) in PGF- $2 \alpha+$ GnRH-treated mares versus PGF-2 $\alpha$-treated mares. 

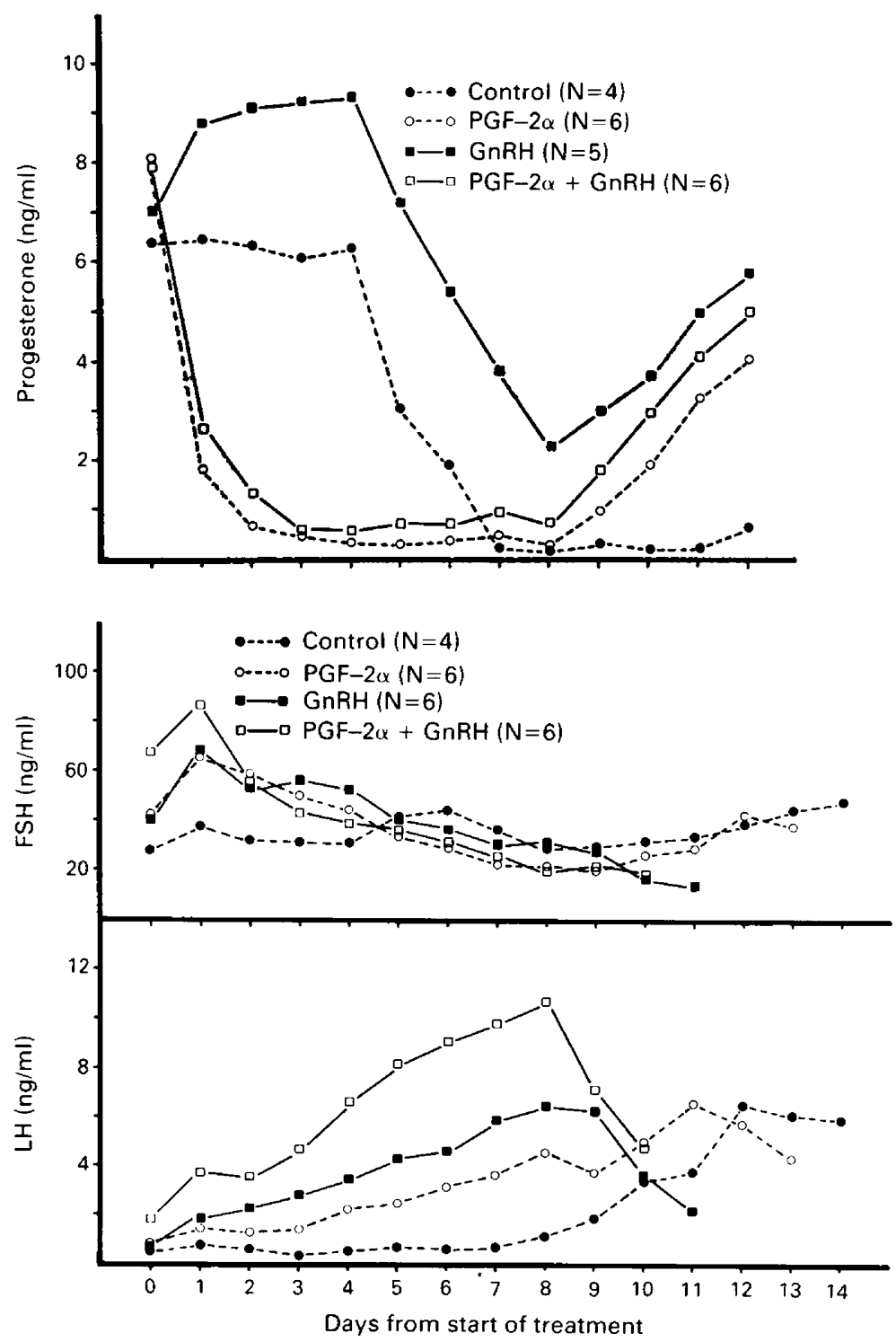

Fig. 1. Serum concentrations of progesterone, LH and FSH from start of treatment (pretreatment is Day 0). All treatments were begun 9 or 10 days after the previous ovulation. Data exclude values from the mare with a persistent corpus luteum (GnRH group). PGF-2 $\alpha, 3 \mathrm{mg}$ alfaprostol; GnRH, $20 \mu \mathrm{g} / \mathrm{h} ; \mathrm{N}=$ number of mares per treatment. Pooled s.e.m. within treatments from the analysis of variance were $0 \cdot 71,0.73,1.35$ and $0.70 \mathrm{ng}$ progesterone $/ \mathrm{ml} 8 \cdot 2,7 \cdot 2$, $9 \cdot 2$ and $12 \cdot 1 \mathrm{ng} \mathrm{FSH} / \mathrm{ml}$, and $0.33,0 \cdot 87,0 \cdot 72$ and $0.90 \mathrm{ng} \mathrm{LH} / \mathrm{ml}$, for the control, PGF-2 $\alpha$, GnRH and PGF- $2 \alpha+$ GnRH treatments, respectively.

This finding is in contrast to that for ewes in which pulsatile administration of $\mathrm{GnRH}$ delayed oestradiol-17ß-induced luteolysis (Adams et al., 1975). However, in the present study, when GnRH was administered in the absence of exogenous PGF- $2 \alpha$, serum progesterone concentrations were increased. This is in contrast to results in heifers which indicated that multiple injections of $\mathrm{GnRH}$ (4 times per day from Days 9 to 12 of the oestrous cycle; Milvae et al., 1984) or pulsatile GnRH $(5 \mu \mathrm{g} / \mathrm{h}$ for $5-11$ days beginning on Day 7 or Day 12 of the luteal phase; Glencross, 1987) failed to 
Table 2. Serum concentrations (mean \pm s.e.m.) of progesterone, LH and FSH 4 days after start of treatment in mares

\begin{tabular}{lcll}
\hline Treatment group* & Progesterone & \multicolumn{1}{c}{ LH } & FSH \\
\hline Control $(\mathrm{N}=4)$ & $6 \cdot 14 \pm 1 \cdot 03^{\mathrm{b}}$ & $0 \cdot 41 \pm 0 \cdot 10^{\mathrm{c}}$ & $31 \cdot 6 \pm 5 \cdot 2$ \\
PGF-2 $\alpha(\mathrm{N}=6)$ & $0 \cdot 40 \pm 0 \cdot 11^{\mathrm{c}}$ & $2 \cdot 19 \pm 0 \cdot 38^{\mathrm{b}, \mathrm{c}}$ & $45 \cdot 0 \pm 6.9$ \\
GnRH $(\mathrm{N}=6)$ & $10 \cdot 37 \pm 1 \cdot 80 \dagger$ & $3 \cdot 50 \pm 0 \cdot 58^{\mathrm{b}}$ & $52 \cdot 8 \pm 15 \cdot 6$ \\
PGF-2 $\alpha+\mathrm{GnRH}$ & $0.65 \pm 0.37^{\mathrm{c}}$ & $6.64 \pm 1 \cdot 16^{\mathrm{a}}$ & $40 \cdot 7 \pm 15.6$ \\
$\quad(\mathrm{~N}=6)$ & &
\end{tabular}

*PGF-2 $\alpha, 3 \mathrm{mg}$ alfaprostol; GnRH, $20 \mu \mathrm{g} / \mathrm{h}$. Treatment began 9 or 10 days after the previous ovulation.

$\dagger$ Data from the one mare with a persistent corpus luteum were omitted from this calculation (see 'Results').

${ }^{\text {a,b.c }}$ Means within a column with different superscripts differ $(P<0 \cdot 05)$.

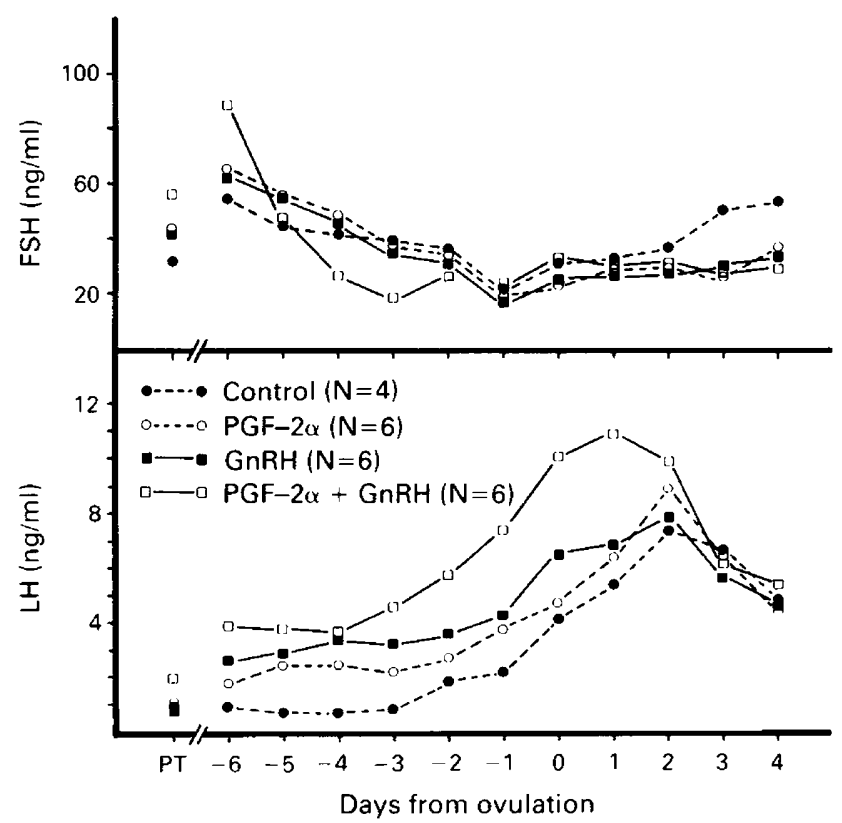

Fig. 2. Serum concentrations of LH and FSH relative to ovulation. PGF-2 $\alpha, 3 \mathrm{mg}$ alfaprostol; GnRH, $20 \mu \mathrm{g} / \mathrm{h} ; \mathrm{N}=$ number of mares per treatment. The pooled s.e.m. from the analysis of variance within treatments were $7.8,4.6,6.8$ and $5.8 \mathrm{ng} \mathrm{FSH} / \mathrm{ml}$, and $0.53,0.71,0.93$ and $1.05 \mathrm{ng} \mathrm{LH} / \mathrm{ml}$, for the control, PGF-2 $\alpha$, GnRH and PGF- $2 \alpha+$ GnRH treatments, respectively. $\mathrm{PT}=$ pretreatment values.

enhance progesterone secretion. Milvae et al. (1984) did, however, find an increase in serum progesterone following treatment with a potent GnRH analogue on Days 9-12 of the oestrous cycle. Taken together, these results suggest a difference in pituitary sensitivity or ovarian response to pulsatile GnRH treatment between the mare and the heifer.

One mare in the GnRH treatment group ovulated 10 days after the start of pulsatile GnRH treatment, despite the continuing presence of high concentrations of progesterone (a nadir of $5 \cdot 10 \mathrm{ng} / \mathrm{ml}, 4$ days after the start of treatment). This cannot be attributed to the GnRH treatment as similar observations have been reported in mares during normal dioestrus (Neely, 1979). We are 
also unable to conclude whether the enhanced progesterone secretion in response to GnRH is the result of a direct action of $\mathrm{GnRH}$ on the ovary, or to the luteotrophic effects of elevated serum $\mathrm{LH}$ values (Table 2). GnRH receptors within the ovary of the mare have not yet been identified. On the other hand, LH receptors in the CL of mares have been identified (Stewart \& Allen, 1979): the numbers of $\mathrm{LH}$ receptors within the CL decrease during spontaneous regression (Roser \& Evans, 1983 ) and after PGF-2 $\alpha$-induced luteolysis (Roser et al., 1982). In addition, passive immunization with an antiserum generated against a horse pituitary fraction during the luteal phase induces premature luteal regession (Pineda et al., 1972). Since there were no significant differences in serum FSH among treatments in the present study (Table 2), we suggest that the enhanced progesterone secretion may be predominantly attributed to elevated serum LH concentrations.

At 4 days after PGF-2 $\alpha$ treatment, serum LH concentrations were not significantly different from those in control mares, and this finding is consistent with that reported by Noden et al. (1978). By contrast, LH concentrations in both GnRH-treated groups were increased significantly compared to controls, and the greatest increase was found in mares treated with PGF- $2 \alpha+$ GnRH (Table 2). Previous studies have reported that injection of GnRH to dioestrous mares can induce a short-term increase in serum LH values (Alexander \& Irvine, 1986), but that administration of exogenous progesterone suppresses serum concentrations of LH in ovariectomized (Garcia \& Ginther, 1976) and cycling (Driancourt \& Palmer, 1982) mares. Therefore, the attenuated LH increase in GnRH-treated mares compared to PGF-2 $\alpha+$ GnRH-treated mares may be due to the former group having a functional $\mathrm{CL}$ and elevated serum concentrations of progesterone.

In every instance, serum LH concentrations in individual mares increased daily throughout the duration of the GnRH infusion. The continuing increase in serum $\mathrm{LH}$ with repeated injections of GnRH is in marked contrast to data from sheep (Cumming et al., 1972; Chakraborty et al., 1974) and cattle (Kinder et al., 1975; Milvae et al., 1984) which showed a decreased pituitary responsiveness and lower mean serum concentrations of $\mathrm{LH}$ after prolonged exposure to $\mathrm{GnRH}$. The present data from cycling mares, as well as those previously reported using seasonally anoestrous mares (Johnson, 1986, 1987), are consistent with the proposal that the pituitary of the mare fails to become refractory to $\mathrm{GnRH}$ even after 10-16 days of pulsatile GnRH treatment. The peak LH concentration in these mares occurred on the day of, or 1 day after ovulation, and this was probably due to GnRH infusion being ended 1 day after an ovulation was detected. The mean periovulatory peak concentration of LH was not different among treatment groups, and this finding was consistent with a previous report (Johnson, 1986).

Although mean concentrations of serum FSH on Day 4 of the experiment were higher in all treatment groups compared to the control group (Table 2), this increase was not statistically significant due to the variation in response between individual mares. Analysis of each treatment group over time, however, showed that mean FSH concentrations decreased during the last 6 days before ovulation (Fig. 3), and the profiles are in general agreement with those found during a normal oestrous cycle (Evans \& Irvine, 1975; Foster et al., 1979). A similar trend has been reported for FSH concentrations before ovulations induced with pulsatile GnRH in seasonally anoestrous mares (Johnson, 1987), and it is suggested that this decline results from the secretion of ovarian inhibin and/or oestradiol.

We conclude that pulsatile administration of GnRH can act as a luteotrophic stimulus, probably by its ability to increase serum LH concentrations for a prolonged period of time. Although the combined treatment of PGF- $2 \alpha+$ GnRH decreased the interval to next ovulation compared to controls, the mean interval to ovulation and variability of response among mares were not markedly different from those of mares treated with PGF-2 $\alpha$ alone.

The study was supported by the New Jersey Agricultural Experiment Station (publication D-06106-02-87). We thank Ms C. Dunn and D. Richard for excellent technical assistance; Dr H. Papkoff for making available the equine LH; Dr L. E. Reichert for the ovine LH; and Ms A. Johnson and Ms C. Notarianni for preparation of the manuscript. 


\section{References}

Adams, T.E., Kinder, J.E., Chakraborty, P.K., Estergreen, V.L. \& Reeves, J.J. (1975) Ewe luteal function influenced by pulsatile administration of synthetic LHRH/FSHRH. Endocrinology 97, 1460-1467.

Alexander, S.L. \& Irvine, C.H.G. (1986) Effect of graded doses of gonadotropin-releasing hormone on serum $\mathrm{LH}$ concentrations in mares in various reproductive states: comparison with endogenously generated pulses. J. Endocr. 110, 19-26.

Chakraborty, P.K., Adams, T.E., Tarnavsky, G.K. \& Reeves, J.J. (1974) Serum and pituitary LH concentrations in ewes infused with LH-RH/FSH-RH. $J$. Anim. Sci. 39, 1150-1157.

Cumming, I.A., Buckmaster, J.M., Cerini, J.C., Cerini, M.E., Chamley, W.A., Findlay, J.K. \& Goding, J.R. (1972) Effect of progesterone on the release of luteinizing hormone induced by a synthetic gonadotropinreleasing factor in the ewe. Neuroendocrinology 10 , 338-348.

Douglas, R.H. \& Ginther, O.J. (1972) Effect of prostaglandin $\mathrm{F}_{2 \mathrm{a}}$ on length of diestrus in mares. Prostaglandins 2, 265-268.

Douglas, R.H. \& Ginther, O.J. (1975) Route of prostaglandin $F_{2 a}$ injection and luteolysis in mares. Proc. Soc. exp. Biol. Med. 148, 263-269.

Douglas, R.H. \& Ginther, O.J. (1976) Concentration of prostaglandins $F$ in uterine venous plasma of anesthetized mares during the estrous cycle and early pregnancy. Prostaglandins 11, 251-260.

Driancourt, M.A. \& Palmer, E. (1982) Seasonal and individual effects on ovarian and endocrine responses of mares to a synchronization treatment with progestagen-impregnated vaginal sponges. J. Reprod. Fert., Suppl. 32, 283-291.

Evans, M.J. \& Irvine, C.H.G. (1975) Serum concentrations of FSH, LH and progesterone during the oestrous cycle and early pregnancy in the mare. $J$. Reprod. Fert., Suppl. 23, 193-200.

Foster, J.P., Evans M.J. \& Irvine, C.H.G. (1979) Differential release of $\mathrm{LH}$ and FSH in cyclic mares in response to synthetic Gn-RH. J. Reprod. Fert. 56, $567-572$.

Garcia, M.C. \& Ginther, O.J. (1976) LH control by estradiol and progesterone in mares. J. Anim. Sci. 43, 285, Abstr.

Ginther, O.J. (1979) Reproductive Biology of the Mare. McNaughton and Gunn, Inc., Ann Arbor, MI.

Glencross, R.G. (1987) Effect of pulsatile infusion of gonadotrophin-releasing hormone on plasma oestradiol-17 $\beta$ concentrations and follicular development during naturally and artificially maintained high levels of plasma progesterone in heifers. $J$. Endocr. 112, 77-85.

Johnson, A.L. (1986) Pulsatile administration of gonadotropin-releasing hormone advances ovulation in cycling mares. Biol. Reprod. 35, 1123-1130.

Johnson, A.L. (1987) Gonadotropin-releasing hormone treatment induces follicular growth and ovulation in seasonally anestrous mares. Biol. Reprod. 36, 1119-1206.

Karsch, F.J., Roche, J.F., Noveroske, J.W., Foster, D.L., Norton, H.W. \& Nalbandov, A.V. (1971) Prolonged maintenance of the corpus luteum of the ewe by continuous infusion of luteinizing hormone. Biol. Reprod. 4, 129-136.

Kiefer, B.L., Roser, J.F., Evans, J.W., Neely, D.P. \& Pacheco, D.A. (1979) Progesterone patterns observed with multiple injections of a PGF- $2 \alpha$ analogue in the cyclic mare. J. Reprod. Fert., Suppl. 27, 237-244.

Kinder, J.E., Adams, T.E., Chakraborty, P.K., Tarnavsky, G.K. \& Reeves, J.J. (1975) Serum LH concentrations and ovarian activity in cows with repetitive administration of LH-RH/FSH-RH. $J$. Anim. Sci. 41, 1650-1652.

Loy, R.G., Buell, J.R., Stevenson W. \& Hamm, D. (1979) Sources of variation in response intervals after prostaglandin treatment in mares with functional corpora lutea. J. Reprod. Fert., Suppl. 27, 229-235.

Malinowski, K., Johnson, A.L. \& Scanes, C.G. (1985) Effects of interrupted photoperiods on the induction of ovulation in anestrous mares. J. Anim. Sci. 61, 951-955.

Milvae, R.A., Murphy, B.D. \& Hansel, W. (1984) Prolongation of the bovine estrous cycle with a gonadotropin-releasing hormone analog. Biol. Reprod. 31, 664-670.

Neely, D.P. (1979) Studies on the control of luteal function and prostaglandin release in the mare. Ph.D. thesis, University of California, Davis.

Nett, T.M., Pickett, B.W. \& Squires, E.L. (1979) Effects of Equimate (ICI-81008) on levels of luteinizing hormone, follicle-stimulating hormone and progesterone during the estrous cycle of the mare. J. Anim. Sci. 48, 69-75.

Noden, P.A., Oxender, W.D. \& Hafs, H.D. (1974) Estrus, ovulation, progesterone and luteinizing hormone after prostaglandin $F_{2 \mathrm{a}}$ in mares. Proc. Soc. exp. Biol. Med. 145, 145-150.

Noden, P.A., Oxender, W.D. \& Hafs, H.D. (1978) Early changes in serum progesterone, estradiol and $\mathrm{LH}$ during prostaglandin $\mathrm{F}_{2 a}$-induced luteolysis in mares. J. Anim. Sci. 47, 666-671.

Pineda, M.H., Ginther, O.J. \& McShan, W.H. (1972) Regression of corpus luteum in mares treated with an antiserum against an equine pituitary fraction. $\mathrm{Am}$.J. vet. Res. 33, 1767-1773.

Roser, J.F. \& Evans, J.W. (1983) Luteal luteinizing hormone receptors during the postovulatory period in the mare. Biol. Reprod. 29, 499-510.

Roser, J.F., Evans, J.W., Mikuckis, G.M., Adams, T.E. \& Hughes, J.P. (1982) Effect of PGF ${ }_{2 \alpha}$ on LH receptors in the equine corpus luteum. J. Reprod. Fert., Suppl. 32, 235-245.

Snedecor, G.W. \& Cochran, W.G. (1967) In Statistical Methods, pp. 329 and 369. Iowa State University Press, Ames, IA.

Stewart, F. \& Allen, W.R. (1979) The binding of FSH; LH and PMSG to equine gonadal tissues. J. Reprod. Fert., Suppl. 27, 431-440.

Zar, J.H. (1984) In Biostatistical Analysis, p. 176. Prentice-Hall, Inc., Englewood Cliffs, NJ.

Received 4 August 1987 